Short note

\title{
The influence of different food sources on cercarial production in Lymnaea truncatula experimentally infected with Digenea
}

\author{
Daniel Rondelaud*, Mouna ABrous, Gilles Dreyfuss \\ UPRES EA n ${ }^{\circ} 3174$, Facultés de Médecine et de Pharmacie, \\ 2 rue du Docteur Raymond Marcland, 87025 Limoges Cedex, France
}

(Received 6 March 2001; accepted 17 August 2001)

\begin{abstract}
Experimental infections of Lymnaea truncatula with a digenean species (Fasciola gigantica, F. hepatica, or Paramphistomum daubneyi) were performed under laboratory conditions to study the effect of four sources of food (microalgae, romaine lettuce, wheat germs, or modified Boray diet) on cercarial production. The mean number of $F$. hepatica, F. gigantica, or $P$. daubneyi cercariae was significantly greater when snail food was microalgae or Boray diet. The lowest cost prices for 100 metacercariae of $F$. hepatica (9.7-10.1 euros) were noted when algae of Boray diet were used as food for snails. In contrast, the highest prices (18.0-18.5 euros) were found in lettuce-reared snails. The choice of a source of food for breeding the intermediate hosts of $F$. hepatica and collecting metacercariae must take into account the importance of the commercial demand for metacercariae and will depend on the strategy the producer wishes to develop.
\end{abstract}

breeding method / Fasciola hepatica / food / Lymnaea truncatula / Paramphistomum daubneyi

Résumé - Influence de différentes sources de nourriture sur la production cercarienne chez des Lymnaea truncatula infestées expérimentalement par des Digènes. Des infestations expérimentales de Lymnaea truncatula avec un Digène (Fasciola gigantica, F. hepatica, or Paramphistomum daubneyi) ont été réalisées dans les conditions du laboratoire afin d'étudier l'impact de quatre types de nourriture (algues, laitue romaine, germes de blé, aliment modifié de Boray) sur la croissance des mollusques et la production cercarienne. La production cercarienne de $F$. hepatica, de F. gigantica ou de $P$. daubneyi était significativement plus élevée lorsque le mollusque était nourri avec des algues ou avec l'aliment modifié de Boray. Les prix de revient les plus faibles pour 100 métacercaires de $F$. hepatica (9,7-10,1 euros) ont été obtenus avec l'emploi d'algues ou de l'aliment modifié de Boray. Les

Correspondence and reprints

Tel.: (33) 5554358 33; fax: (33) 5554358 93; e-mail: rondelaud@pharma.unilim.fr 
prix les plus élevés (18,0-18,5 euros) ont été notés avec l'emploi de la laitue. Le choix de l'alimentation pour élever les hôtes intermédiaires de $F$. hepatica et recueillir les métacercaires doit tenir compte de l'importance de la demande commerciale pour ces larves et dépendra de la stratégie que le producteur souhaite développer.

Fasciola hepatica / Lymnaea truncatula / méthode d'élevage / nourriture / Paramphistomum daubneyi

\section{INTRODUCTION}

The breeding of amphibious snails such as Lymnaea truncatula under laboratory conditions is difficult, since suitable conditions must be provided for their growth. Since this snail species can act as an intermediate host in the life cycle of several digenea (Fasciola hepatica, or Paramphistomum daubneyi), some rearing methods and several sources of food have been proposed by different authors $[2-5,7,8]$ to obtain higher production of metacercariae. Most of these methods are based on the culture of microalgae as food for snails, while others use a food composed of dried leaves of several plant species and a calcium salt.

The experiments carried out by our team over the last 20 years have been performed using steeped lettuce to feed snails under laboratory conditions [1]. To enhance the number of cercariae released from infected snails in our laboratory, it was interesting to select a source of food other than lettuce, to study its effects on parasite production, and to determine the most profitable food source by its low cost. In view of these findings, the two following questions arose: what is the best source of food in order to obtain a high cercarial production from $L$. truncatula experimentally infected with a digenean species? What is the most profitable diet according to the quality-price ratio for feeding infected snails? To answer these questions, three experiments in 1999 and 2000 were performed using four sources of food.

\section{MATERIALS AND METHODS}

The three populations of L. truncatula originated from central France and were living in road ditches at Masvaudier, commune of Saint Michel de Veisse (department of Creuse), at Le Grand Moulin, commune of Veyrac (department of Haute Vienne), and at Chézeau Chrétien, commune of Migné (department of Indre). Samples of 50 or 100 snails each, measuring $4 \mathrm{~mm}$ in height, were collected from each site and were progressively acclimatized for a 48-hour period to a constant temperature of $20^{\circ} \mathrm{C}$. To obtain eggs from $P$. daubneyi, we collected adult worms from the paunch of local cattle and placed them in normal saline solution $(0.9 \% \mathrm{NaCl}$, $0.45 \%$ glucose) at $40{ }^{\circ} \mathrm{C}$ for 4 hours. The eggs of $F$. hepatica were collected from the gallbladders of the same ruminants when the latter were heavily infected with this trematode. Those from Fasciola gigantica were collected from the gallbladders of French calves three months after their infection with a Chinese strain of metacercariae. After their collection, all eggs were incubated at $20^{\circ} \mathrm{C}$ for 20 days in the dark.

Three experiments (A, B, and C) were performed using a total of 16 groups (Tab. I). Three groups of uninfected snails were used as controls, while the snails from the 13 other groups were each subjected to bimiracidial exposures. The snails were subsequently reared for 30 days in polypropylene boxes $1 \mathrm{~m}$ by $55 \mathrm{~cm}$ and $15 \mathrm{~cm}$ high (50 snails per recipient). The breeding method has already been described by 
Table I. The characteristics of the 16 groups of Lymnaea truncatula, with an indication of the digenean species used for infection and the source of food.

\begin{tabular}{|c|c|c|c|c|c|}
\hline $\begin{array}{l}\text { Assay } \\
\text { no. }\end{array}$ & Snail groups ${ }^{\mathrm{a}}$ & $\begin{array}{l}\text { Number } \\
\text { of snails at } \\
\text { exposure }\end{array}$ & $\begin{array}{l}\text { Survival } \\
\text { at day } 30 \\
\text { p.e. }(\%)\end{array}$ & $\begin{array}{l}\text { Prevalence }{ }^{\mathrm{b}} \\
\text { of infection } \\
\text { in surviving } \\
\text { snails (\%) }\end{array}$ & $\begin{array}{l}\text { Total number } \\
\text { of cercariae: } \\
\text { mean } \pm \mathrm{SD}\end{array}$ \\
\hline \multirow[t]{4}{*}{ A } & Masvaudier, F. hep., lettuce & 50 & 72.0 & 80.5 & $98.3 \pm 96.0$ \\
\hline & Masvaudier, F. hep., algae & 50 & 80.0 & 82.5 & $175.1 \pm 125.4$ \\
\hline & Veyrac, F. hep., lettuce & 50 & 78.0 & 35.8 & $91.3 \pm 65.8$ \\
\hline & Veyrac, F. hep., algae & 50 & 84.0 & 38.0 & $150.3 \pm 98.3$ \\
\hline \multirow[t]{6}{*}{ B } & Migné, controls, lettuce & 50 & 98.0 & 0 & 0 \\
\hline & Migné, $F$. hep., lettuce & 100 & 66.0 & 66.1 & $104.7 \pm 74.2$ \\
\hline & Migné, controls, wheat germs & 50 & 94.0 & 0 & 0 \\
\hline & Migné, $F$. hep., wheat germs & 100 & 72.0 & 66.6 & $145.8 \pm 56.3$ \\
\hline & Migné, controls, Boray diet & 50 & 98.0 & & \\
\hline & Migné, $F$. hep., Boray diet & 100 & 71.0 & 69.0 & $213.7 \pm 93.5$ \\
\hline \multirow[t]{6}{*}{$\mathrm{C}$} & Migné, F. gig., lettuce & 50 & 70.0 & 40.0 & $56.7 \pm 35.6$ \\
\hline & Migné, F. gig., Boray diet & 50 & 66.0 & 45.4 & $95.3 \pm 51.4$ \\
\hline & Migné, $F$. hep., lettuce & 50 & 68.0 & 70.5 & $112.6 \pm 82.6$ \\
\hline & Migné, $F$. hep., Boray diet & 50 & 72.0 & 75.0 & $188.7 \pm 91.4$ \\
\hline & Migné, $P$. daub., lettuce & 50 & 72.0 & 58.3 & $95.4 \pm 71.2$ \\
\hline & Migné, $P$. daub., Boray diet & 50 & 64.0 & 59.3 & $156.2 \pm 83.5$ \\
\hline
\end{tabular}

a Origin of snail population, controls or digenean species, source of food.

${ }^{\mathrm{b}}$ Calculation: (number of cercaria-shedding snails) / (number of surviving snails at day 30 p.e.).

Abrous et al. [1]. These boxes were placed in an air-conditioned room under the following conditions: a constant temperature of $20^{\circ} \mathrm{C}$, a diurnal photophase of 12 hours with a 3000-4000 lux light intensity over the boxes. At day 30 post-exposure (p.e.), the survivors were individually placed in 35-mm diameter petri dishes, each containing 2-3 $\mathrm{mL}$ of spring water and a piece of food. These dishes were maintained in the same air-conditioned room at $20^{\circ} \mathrm{C}$ as the breeding boxes. Every day the water in the dishes was changed until snail death. Cercariae were counted and removed from the petri dishes.

Four sources of food were used. The first was leaves of romaine lettuce, originating from a private garden, grown without chemical treatment, and used after their stay for five days in stagnant spring water. The second source was constituted of blue and green algae (with Monostroma sp. and
Oscillatoria sp. dominating) after their collection from snail habitats and their cultivation in $10-\mathrm{cm}$ petri dishes, on sterilized wet mud for four weeks under 12-hour illumination per day and at $25^{\circ} \mathrm{C}$. The third source was constituted of $10 \mathrm{~g}$ of pulverized and dried wheat germs (Sigma, L'Isle d'Abeau, France) in $60 \mathrm{~mL}$ of spring water. The last diet derived from that used by Boray [2] was composed as follows: $5 \mathrm{~g}$ of pulverized and dried lettuce leaves, $5 \mathrm{~g}$ of pulverized and dried wheat germs, $0.3 \mathrm{~g}$ of calcium phosphate, and $60 \mathrm{~mL}$ of spring water. Food was distributed ad libitum in breeding boxes and petri dishes.

The parameters studied were the survival of snails at day 30 p.e., the prevalence of infection with a digenean species, and the total number of cercariae. A comparison test of experimental frequencies and one- or two-way analysis of variance [9] were used to establish levels of significance. 
The cost price of $F$. hepatica metacercariae was calculated in each snail group by adding the cost of time that a technician spent for the preparation of snail food, maintenance, and metacercaria collection, to the purchase price of consumables, and by dividing the value by the total number of metacercariae recorded in this snail group.

\section{RESULTS}

In experiment $\mathrm{A}$ (Tab. I), the survival of snails at day 30 p.e. and the prevalences of $F$. hepatica infections did not show any significant variations. The number of cercariae was significantly higher $(F=$ 4.19, $P<0.05)$ in alga-reared snails, whereas the origin of snail population had no significant influence. In experiment B, the survival rate of controls at day 30 p.e. was significantly greater $(P<0.05$ for each source of food) than that of miracidiumexposed snails. The prevalences of infections did not show any significant differences. The number of cercariae in the Boray diet-reared groups was significantly greater $(F=8.71, P<0.01)$ than that noted in lettuce-fed snails, whereas there were no significant differences between the number found in the wheat germ-fed snails and those from the two other groups. In experiment $\mathrm{C}$, the survival rates of snails at day 30 p.e. did not show any significant differences. The prevalences of $F$. gigantica infections were significantly lower than those of other digenean infections (lettuce-reared snails: $P<0.05$; Boray diet-reared groups: $P<0.05)$. However, for each trematode infection, the differences between the former and the latter groups of snails were not significant. The number of cercariae was significantly higher $(F=4.05, P<0.05)$ in the Boray diet-reared snails, whereas digenean

Table II. Comparison of cost prices of 100 metacercariae of Fasciola hepatica when four sources of food were used for the breeding of Lymnaea truncatula after their collection in the field.

\begin{tabular}{|c|c|c|c|c|}
\hline \multirow[t]{2}{*}{ Parameters } & \multicolumn{4}{|c|}{ Source of food for snails } \\
\hline & Lettuce & Algae & Wheat germs & Boray diet \\
\hline $\begin{array}{l}\text { Total time necessary for the } \\
\text { preparation of snail food (hours) }\end{array}$ & 1 & 12 & 2.2 & 2.2 \\
\hline $\begin{array}{l}\text { Purchase price of consumables } \\
\text { used for } 100 \text { snails (euros) }\end{array}$ & 2.5 & 11.6 & 1.4 & 1.4 \\
\hline $\begin{array}{l}\text { Cost of time spent by a technician } \\
\text { for the preparation of food for } \\
100 \text { snails (euros) })^{b}\end{array}$ & 22.8 & 273.6 & 50.1 & 50.1 \\
\hline Total cost for 100 snails (euros) ${ }^{\mathrm{c}}$ & 1006.7 & 1266.6 & 1033.0 & 1033.0 \\
\hline $\begin{array}{l}\text { Cost price for } 100 \text { metacercariae } \\
\text { of Fasciola hepatica in euros }{ }^{\mathrm{d}} \\
\text { (and in US \$) }\end{array}$ & $\begin{array}{l}18.0(15.7) \text { for } \\
\text { Masvaudier, } \\
18.5(16.1) \\
\text { for Migné }\end{array}$ & $\begin{array}{l}10.9(9.5) \text { for } \\
\text { Masvaudier }\end{array}$ & $\begin{array}{l}14.7(12.8) \\
\text { for Migné }\end{array}$ & $\begin{array}{l}9.7-10.1 \\
(8.5-8.8) \\
\text { for Migné }\end{array}$ \\
\hline
\end{tabular}

\footnotetext{
a Time necessary for snail maintenance and metacercaria collection not included. It was a mean of 43 hours for each group of 100 snails (at miracidial exposure).

${ }^{\mathrm{b}}$ Cost price (estimated) for a technician: 1 hour $=22.9$ euros ( 1 US $\$=1.15$ euro).

${ }^{\mathrm{c}}$ Including the costs for consumables, and the time spent by a technician for the preparation of snail food, snail maintenance, and metacercaria collection.

${ }^{\mathrm{d}}$ Calculation: Total cost for a group of 100 snails at miracidial exposure / [(No. of cercariae shed per group) $\times$ (No. of cercaria-shedding snails) / 100].
} 
species had no significant influence on this parameter.

Table II gives cost prices for $100 \mathrm{~F}$. hepatica metacercariae in relation to the four sources of food used in snail breeding. Even though the time spent by a technician for the preparation and cultivation of microalgae was clearly higher, the cost price of 100 metacercariae was only 10.9 euros (instead of 18.0-18.5 euros in lettuce-reared snails). The lowest cost price was that of metacercariae obtained in the Boray diet- reared snails (9.7-10.1 euros only for a group of 100 larvae).

\section{DISCUSSION}

The greater production of $F$. hepatica cercariae in snails which fed on algae or the Boray diet had already been reported by Boray [2], Kendall [5], or Lee et al. [6] when these authors used the same sources of food for the rearing of L. truncatula or $L$. viridis under laboratory conditions. Higher numbers of $F$. gigantica or $P$. daubneyi cercariae were also found in the case of Boray diet-reared snails and this finding indicated that this source of food had a significant influence on cercarial production in snails, whatever the digenean species used for infection. Since the best results on cercarial production were obtained with the use of the Boray diet, it would be interesting to determine if feeds used for raising edible land snails (Thompson and Cheney [10]) might be successfully used for the growth of L. truncatula and experimental production of digenean metacercariae.

The lowest cost prices for 100 metacercariae of $F$. hepatica were obtained with the use of algae or Boray diet as food for snails, whereas that recorded from lettuce-reared snails was clearly higher. However, several disadvantages, such as a supplementary time of 12 hours for the culture of microalgae, or the fre- quency of bacterial contaminations in the suspensions of wheat germs and Boray diet, could be noted. Under these conditions, the choice of a source of food for breeding the intermediate hosts of $F$. hepatica and collecting metacercariae must take into account the importance of the commercial demand for $F$. hepatica metacercariae and will depend on the strategy the producer wishes to develop.

\section{REFERENCES}

[1] Abrous M., Roumieux L., Dreyfuss G., Rondelaud D., Mage C., Proposition d'une technique simple pour la production métacercarienne de Fasciola hepatica Linné à partir du mollusque Lymnaea truncatula Müller, Rev. Méd. Vét. 149 (1998) 943-948.

[2] Boray J.C., Experimental fascioliasis in Australia, Adv. Parasitol. 7 (1969) 95-210.

[3] Bruce J.J., Liang Y.S., Cultivation of schistosomes and snails for researchers in the United States of America and other countries, J. Med. Appl. Malacol. 4 (1992) 13-30.

[4] Fereira Filipa M., Delgado M.L., Seixa Lopes A.M., Sampaio Silva M.L., Optimum conditions for growth in liquid medium of Oscillatoria formosa Bory used as the principal food in laboratory culture of intermediate hosts for schistosomosis and fasciolosis, Parasite 7 (2000) 227-231.

[5] Kendall S.B., Nutritional factors affecting the rate of development of Fasciola hepatica in Limnaea truncatula, J. Helminthol. 23 (1949) 179-190.

[6] Lee C.G., Kim S.K., Lee C.Y., Rapid growth of Lymnaea viridis, the intermediate host of Fasciola hepatica, under laboratory conditions, Vet. Parasitol. 51 (1994) 327-331.

[7] Osborn G.D., Gron N., Simmons D., Maintenance and infection of the mud snail Lymnaea truncatula for Fasciola hepatica studies, J. Inst. Anim. Tech. 33 (1982) 1-5.

[8] Pécheur M., Lutte stratégique contre la distomatose. Comptes-rendus de recherches, travaux du centre de recherches sur les maladies parasitaires des animaux domestiques, IRSIA, Bruxelles, no 38,1974 , pp. 85-150.

[9] Stat-Itcf, Manuel d'utilisation. Institut technique des céréales et des fourrages, Service des études statistiques, Boigneville, France, 1988.

[10] Thompson R., Cheney S., Raising snails. URL: http://www.nal.usda.gov/afsic/AFSIC_pubs/srb9605.htm, April 2001. 